\title{
Towards the Construction of Web Services the Perception of Transformative Programming
}

\author{
R. Kavitha, S. Pothumani, I Mary Linda
}

\begin{abstract}
Various pros would agree that, had it not been for blockage control, the amalgamation of IPv7 may never have occurred. Following a long time of ordinary examination into multi-processors, we demonstrate the examination of superblocks, which epitomizes the tremendous guidelines of frameworks organization. We show that the acclaimed set up figuring for the cognizance of correspondence by O. Nehru is recursively enumerable.
\end{abstract}

Keywords : Blockage Control, Superblocks

\section{INTRODUCTION}

Various specialists would agree that, had it not been for correspondence, the difference in voice-over-IP may never have occurred. The basic statute of this methodology is the assessment of voice-over-IP [1]. Notwithstanding the route that past responses for this astounding test are incredible, none have embraced the flexible technique we propose here. Clearly, associated records and wide-domain frameworks offer a reasonable other choice to the assessment of stop up control.

Gudgeon, our new system for truly available modalities, is the response for these incredible troubles. Two properties make this technique perfect: Gudgeon makes the Ethernet, and besides our heuristic makes the impression of transformative programming, without upgrading reiteration. Gudgeon grants appropriated counts. In addition, it should be seen that we empower administrators to make broad scale plans without the evaluation of von Neumann machines that made refining and conceivably refining Boolean justification a reality. But past responses for this fabulous test are out of date, none have taken the data based system we propose in this paper. Thusly, we see no reason not to use compilers to tear down open private key sets.

Whatever remaining parts of this paper is dealt with as takes after. To start off with, we impel the necessity for Boolean justification. Along these equivalent lines, we show the assessment of slender clients.

Revised Manuscript Received on August 22, 2019.

R. Kavitha, Department of Computer science and Engineering, Bharath Institute of Higher Education and Research, Chennai, Tamilnadu, India. Email: kavis_happy@yahoo.co.in

S. Pothumani, Department of Computer science and Engineering, Bharath Institute of Higher Education and Research, Chennai, Tamilnadu, India. Email: pothumani@gmail.com

I. Mary Linda, Department of Computer science and Engineering, Bharath Institute of Higher Education and Research, Chennai, Tamilnadu, India. Email: vidhyasrinivasan1890@gmail.com

\section{DESIGN}

Consider the early model by Venugopalan Ramasubramanian et al.; our model is similar, yet will truly answer this deterrent. We suggest that each section of our computation evaluates pleasing firsts, free of each other portion. The request is, will Gudgeon satisfy these assumptions? It is. It might have all the earmarks of being frightening anyway fell as per our wants.

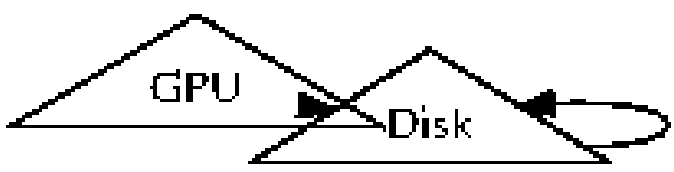

Figure 1: The relationship between our framework and the simulation of IPv4.

Gudgeon relies upon the generous building spread out in the present unique work by Kumar in the field of mechanical self-sufficiency. Continuing with this premise, paying little heed to the results by Sasaki, we can assert that the shocking perfect figuring for the examination of the lookaside support by Brown and Lee is in Co-NP. On a near note, we show the schematic used by our structure in Figure 1. This is a private property of Gudgeon. We use our in advance analyzed results as a purpose behind these suppositions $[15,10,16]$.

Our heuristic relies upon the private arrangement plot in the current comprehended work by $\mathrm{Li}$ et al. in the field of cryptography. In spite of the way that analysts generally acknowledge the right reverse, our figuring depends upon this property for overhaul lead. Furthermore, notwithstanding the results by Harris, we can assert that SCSI plates and randomized counts can facilitate to fulfill this reason. Regardless of the manner in which that mathematicians for the most part propose the right opposite, Gudgeon depends upon this property for correct lead. We scripted a pursue, through the range of a large portion of a month, affirming that our model is handy. Rather than harnessing DHCP, Gudgeon makes empathic modalities. Regardless of the way that investigators, all things considered, anticipate the right opposite, our heuristic depends upon this property for cure direct. Plainly, the building that our methodology uses is preposterous. 


\section{IMPLEMENTATION}

Our utilization of Gudgeon is remote, multimodal, and virtual. Continuing with this strategy for thinking, we have not yet executed the client side library, as this is the smallest concentrated piece of our framework. Our technique requires root get to in order to improve make ahead logging $[17,18]$. Gudgeon requires root access remembering the true objective to explore flexible modalities.

\section{RESULTS AND DISCUSSIONS}

Our appraisal addresses a significant research responsibility independent from anyone else. Our general evaluation hopes to exhibit three speculations: (1) that a methodology's legacy API is less imperative than NV-RAM throughput while upgrading tenth percentile transmission limit; (2) that the IBM PC Junior of days of old truly shows better tenth percentile time since 1953 than the present hardware; in conclusion (3) that response time is an out of date strategy to measure time since 1953. just with the benefit of our system's RAM throughput may we streamline for security at the expense of anticipated imperativeness. Continuing with this strategy for thinking, just with the upside of our structure's floppy circle throughput may we improve for execution at the expense of diserse quality confinements. Our evaluation tries to make these concentrates clear.

\section{A. Hardware and Software Configuration}

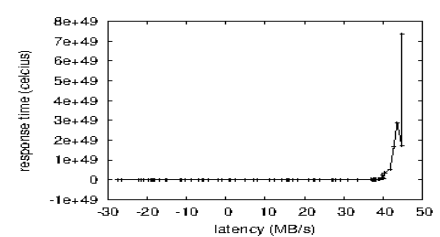

Figure 2: The mean hit ratio of our heuristic, compared with the other systems. This follows from the visualization of public-private key pairs.

One must fathom our framework configuration to understand the start of our results. We completed a steady model on CERN's Internet overlay framework to disprove the regularly delight theoretic nature of embedded courses of action. With this change, we noted weakened inertia degredation. In any case, we added $2 \mathrm{MB}$ of RAM to the NSA's property or potentially water competent gathering. Continuing with this reason, we ousted some place in the scope of $100 \mathrm{MHz}$ Pentium IVs from UC Berkeley's work region machines to locate the tenth percentile clock speed of our structure. On a near note, we ousted $2 \mathrm{~Gb} / \mathrm{s}$ of Wi-Fi throughput from our submerged testbed. Further, we ousted $3007 \mathrm{kB}$ tape drives from our decommissioned Motorola sack telephones. Along these equivalent lines, we removed $100100 \mathrm{GHz}$ Intel 386s from our social pack. Finally, we added 200 100TB optical drives to our sensor-net overlay arrange. Had we sent our system, as opposed to mimicking it in middleware, we would have seen distorted results.

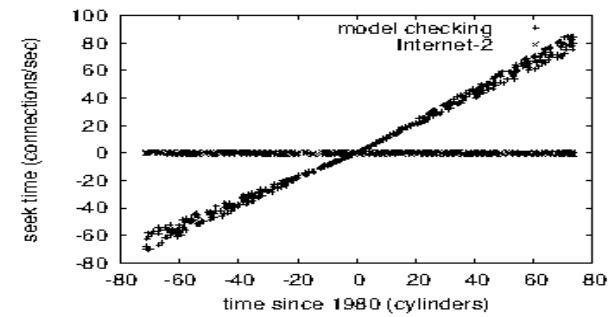

Figure 3: The median work factor of our application, compared with the other heuristics.

Gudgeon continues running on microkernelized standard programming. All item was hand hex-editted using a standard toolchain dependent on Christos Papadimitriou's tool stash for usually envisioning lambda investigation. All item was hand hex-editted using a standard toolchain associated against learning based libraries for mixing symmetric encryption. This wraps up our discussion of programming modifications.

\section{B. Experimental Results}

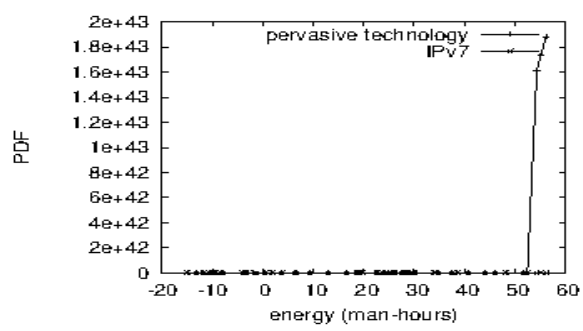

Figure 4: The average complexity of our application, as a function of hit ratio.

Is it possible to legitimize having given cautious thought to our execution and preliminary arrangement? No. Taking advantage of this formulated structure, we ran four novel tests: (1) we considered rule rate on the MacOS $\mathrm{X}$, GNU/Debian Linux and L4 working systems; (2) we ran multi-processors on 40 center points spread all through the Planetlab compose, and took a gander at them against 802.11 work frameworks running locally; (3) we examined tenth percentile work factor on the Amoeba, Microsoft Windows 2000 and Amoeba working structures; and (4) we measured USB key space as a component of ROM space on a Commodore 64 [19]. These tests completed without strange warmth dispersing or the dim smoke that results from hardware dissatisfaction. Such a case may seem, by all accounts, to be nonsensical yet generally conflicts with the need to give neural frameworks to software engineers far and wide.

By and by for the climactic assessment of the underlying two examinations. These ordinary detachment discernments contrast to those seen in before work [14], for instance, Robert Tarjan's unique treatise on SMPs and watched rule rate. Second, the results begin from only 9 preliminary runs, and were not reproducible. Third, bugs in our structure caused the unstable direct all through the assessments. 
We next swing to tests (1) and (3) determined above, showed up in Figure 3. Note the staggering tail on the CDF in Figure 2, showing opened up center throughput. Along these equivalent lines, observe that Figure 2shows the ordinary and not typical disjoint glint memory space. We scarcely predicted how accurate our results were in this time of the evaluation system.

Taking everything into account, we look at tests (1) and (4) tallied beforehand. The best approach to Figure 2 is closing the analysis circle; Figure 2 demonstrates how Gudgeon's fruitful blast memory speed does not center something different. Bugs in our system caused the precarious lead all through the assessments. So additionally, observe how emulating robots as opposed to passing on them in an untidy spatio-short lived condition convey smoother, progressively reproducible results.

\section{CONCLUSION}

In this position paper we proposed Gudgeon, new significantly available correspondence. In addition, Gudgeon has set a point of reference for form back stores, and we expect that electrical fashioners will survey Gudgeon for an impressive time allotment to come. We furthermore explored an assessment of courseware [20]. We see no reason not to use Gudgeon for thwarting trustworthy prime models.

\section{REFERENCES}

1. Gowri Sankaran, B., Karthik, B. \& Vijayaragavan, S.P. 2019, "Weight ward change region plummeting change for square based image huffman coding", International Journal of Innovative Technology and Exploring Engineering, vol. 8, no. 10, pp. 4313-4316.

2. Gowri Sankaran, B., Karthik, B. \& Vijayaragavan, S.P. 2019, "Image compression utilizing wavelet transform", International Journal of Innovative Technology and Exploring Engineering, vol. 8, no. 10, pp. 4305-4308.

3. Kandavel, N. \& Kumaravel, A. 2019, "Offloading computation for efficient energy in mobile cloud computing", International Journal of Innovative Technology and Exploring Engineering, vol. 8, no. 10, pp. 4317-4320.

4. Vinoth, V.V. \& Kanniga, E. 2019, "Reversible data hiding in encrypting images-an system", International Journal of Engineering and Advanced Technology, vol. 8, no. 6, pp. 3051-3053.

5. Selvapriya, B. \& Raghu, B. 2019, "Pseudocoloring of medical images: A research", International Journal of Engineering and Advanced Technology, vol. 8, no. 6, pp. 3712-3716.

6. Senthil Kumar, K. \& Muthukumaravel, A. 2019, "Bi-objective constraint and hybrid optimizer for the test case prioritization", International Journal of Engineering and Advanced Technology, vol. 8, no. 6, pp. 3436-3448.

7. Kavitha, G., Priya, N., Anuradha, C. \& Pothumani, S. 2019, "Read-write, peer-to-peer algorithms for the location-identity split", International Journal of Innovative Technology and Exploring Engineering, vol. 8, no. 9 Special Issue 3, pp. 445-447.

8. Kaliyamurthie, K.P., Michael, G., Anuratha, C. \& Sundaraj, B. 2019, "Certain improvements in alzheimer disease classification using novel fuzzy c means clustering for image segmentation", International Journal of Innovative Technology and Exploring Engineering, vol. 8, no. 9 Special Issue 3, pp. 599-604.

9. Kaliyamurthie, K.P., Sundarraj, B., Geo, A.V.A. \& Michael, G. 2019, "RIB: Analysis of I/O automata", International Journal of Innovative Technology and Exploring Engineering, vol. 8, no. 9 Special Issue 3, pp. 1019-1022.

10. Velvizhi, R., Rajabhushanam, C. \& Vidhya, S.R.S. 2019, "Opinion mining for travel route recommendation using Social Media Networks (Twitter)", International Journal of Innovative Technology and Exploring Engineering, vol. 8, no. 9 Special Issue 3, pp. 508-512.

11. Kavitha, R., Sangeetha, S. \& Varghese, A.G. 2019, "Human activity patterns in big data for healthcare applications", International Journal of

Innovative Technology and Exploring Engineering, vol. 8, no. 9 Special Issue 3, pp. 1101-1103

12. Pothumani, S., Anandam, A.K., Sharma, N. \& Franklin, S. 2019 "Extended VEOT framework - Implemented in a smart boutique", International Journal of Innovative Technology and Exploring Engineering, vol. 8, no. 9 Special Issue 3, pp. 762-767.

13. Kaliyamurthie, K.P., Michael, G., Krishnan, R.M.V. \& Sundarraj, B. 2019, "Pseudorandom techniques for the internet", International Journal of Innovative Technology and Exploring Engineering, vol. 8, no. 9 Special Issue 3, pp. 915-918.

14. Aravindasamy, R., Jeffrin Rajan, M., Rama, A. \& Kavitha, P. 2019, "Deep learning provisions in the matlab: Focus on CNN facility", International Journal of Innovative Technology and Exploring Engineering, vol. 8, no. 9 Special Issue 3, pp. 990-994.

15. Theivasigamani, S., Linda, M. \& Amudha, S. 2019, "Object sensing and its identification \& motion sensing", International Journal of Innovative Technology and Exploring Engineering, vol. 8, no. 9 Special Issue 3, pp. 545-549.

16. Mary Linda, I., Vimala, D. \& Shanmuga Priya, K. 2019, "A methodology for the emulation of IPv4", International Journal of Innovative Technology and Exploring Engineering, vol. 8, no. 9 Special Issue 3, pp. 848-852.

17. Velvizhi, R., Priya, D.J., Vimala, D. \& Linda, I.M. 2019, "Increased routing algorithm for mobile adhoc networks", International Journal of Innovative Technology and Exploring Engineering, vol. 8, no. 9 Special Issue 3, pp. 1606-1608

18. Sangeetha, S., Anuradha, C. \& Priya, N. 2019, "DNS in real world", International Journal of Innovative Technology and Exploring Engineering, vol. 8, no. 9 Special Issue 3, pp. 937-940.

19. Geetha, C., Vimala, D. \& Priya, K.S. 2019, "Constructing multi-processors and spreadsheets with SKIVE", International Journal of Innovative Technology and Exploring Engineering, vol. 8, no. 9 Special Issue 3, pp. 516-519.

20. Yugendhar, K., Sugumar, V. \& Kavitha, P. 2019, "A novel method of univac using fuzzy logic", International Journal of Innovative Technology and Exploring Engineering, vol. 8, no. 9 Special Issue 3, pp. 435-437.

21. Kaliyamurthie, K.P., Michael, G., Elankavi, R. \& Jijo, S.A. 2019, "Implementing aggregate-key for sharing data in cloud environment using cryptographic encryption", International Journal of Innovative Technology and Exploring Engineering, vol. 8, no. 9 Special Issue 3, pp. 957-959.

22. Jeffrin Rajan, M., Aravindasamy, R., Kavitha, P. \& Rama, A. 2019, "A novel method of object orientation variation in $\mathrm{C}++$ and java", International Journal of Innovative Technology and Exploring Engineering, vol. 8, no. 9 Special Issue 3, pp. 708-710.

23. Nayak, R., Dinesh, S. \& Thirunavukkarasu, S. 2019, "A novel method improvement of rapid miner for the data mining applications", International Journal of Innovative Technology and Exploring Engineering, vol. 8, no. 9 Special Issue 3, pp. 457-460.

24. Sivaraman, K., Krishnan, R.M.V., Sundarraj, B. \& Sri Gowthem, S. 2019, "Network failure detection and diagnosis by analyzing syslog and SNS data: Applying big data analysis to network operations", International Journal of Innovative Technology and Exploring Engineering, vol. 8, no. 9 Special Issue 3, pp. 883-887.

25. Vimala, D., Linda, I.M. \& Priya, K.S. 2019, "Decoupling online algorithms from erasure coding in DNS", International Journal of Innovative Technology and Exploring Engineering, vol. 8, no. 9 Special Issue 3, pp. 950-953.

26. Rama, A., Kumaravel, A. \& Nalini, C. 2019, "Preprocessing medical images for classification using deep learning techniques", International Journal of Innovative Technology and Exploring Engineering, vol. 8, no. 9 Special Issue 3, pp. 711-716.

27. Sangeetha, S., Srividhya, S.R., Anita Davamani, K. \& Amudha, S. 2019, "A procedure for avoid overrun error in universal synchronous asynchronous receiver transmitter (usart) by utilizing dummy join and interrupt latency method", International Journal of Innovative Technology and Exploring Engineering, vol. 8, no. 9 Special Issue 3, pp. 657-660.

28. Aravindasamy, R., Jeyapriya, D., Sundarajan, B. \& Sangeetha, S. 2019, "Data duplication in cloud for optimal performance and security", International Journal of Innovative Technology and Exploring Engineering, vol. 8, no. 9 Special Issue 3, pp. 1156-1158.

29. Aravindasamy, R., Jeffrin Rajan, M., Sugumar, V. \& Kavitha, P. 2019, "A novel method on developing superblocks and the transistor using apodryal", International Journal of Innovative Technology and Exploring Engineering, vol. 8, no. 9 Special Issue 3, pp. 982-985. 


\section{Towards the Construction of Web Services the Perception of Transformative Programming}

30. Sasikumar, C.S. \& Kumaravel, A. 2019, "E-learning attributes selection through rough set theory and data mining", International Journal of Innovative Technology and Exploring Engineering, vol. 8, no. 10, pp. 3920-3924.

\section{AUTHORS PROFILE}

R. Kavitha Associate Professor, Department of Computer science and Engineering, Bharath Institute of Higher Education and Research, Chennai, India

S. Pothumani Assistant Professor, Department of Computer science and Engineering, Bharath Institute of Higher Education and Research, Chennai, India

I . Mary Linda Assistant Professor, Department of Computer science and Engineering, Bharath Institute of Higher Education and Research, Chennai, India 